\title{
Islam dalam Bingkai Ke-Indonesiaan: Toleransi Sebagai Pilar keberagamaan yang Humanis
}

\author{
Setiamin $^{1}$ \\ ${ }^{1}$ Institut Agama Islam Negeri Tulungagung \\ Email: ${ }^{1}$ setia.amin00@gmail.com
}

\section{Tersedia Online di \\ http://www.jurnal.unublitar.ac.id/ index.php/briliant}

\section{Sejarah Artikel \\ Diterima pada 5 November 2017 \\ Disetuji pada 5 November 2017 \\ Dipublikasikan pada 13 \\ November 2017 Hal. 512-521}

\section{Kata Kunci:}

Islam, toleransi, tradisi Islam, Islam inklusif.

\section{DOI:}

http://dx.doi.org/10.28926/briliant .v2i4.114

\begin{abstract}
Abstrak: Tulisan ini mendiskusikan tentang bagaimana sikap sebagian masyarakat muslim Indonesia dalam beragama. Serta mengungkap terjadinya kesenjangan antara pesan ideal Islam dan realita yang ada. Terjadi pula oposisi antara pemahaman yang disuarakan dengan praktik yang dilakukan. Kesenjangan tersebut disebabkan oleh beberapa faktor. Tulisan ini kemudian menghasilkan kesimpulan bahwa Islam adalah agama yang menjunjung tinggi hak-hak manusia. Islam merupakan solusi atas permasalahan, bukan sumber permasalahan. Kehadiran Islam sesungguhnya untuk menyatukan umat, bukan memecah-belah kebersamaan. Dalam hal ini, toleransi menjadi solusi terpenting untuk mewujudkan kedamaian dan persaudaraan dalam bingkai kehidupan masyarakat Indonesia yang plural dan multikultural.
\end{abstract}

Sejak lahirnya, ajaran Islam sudah membawa misi persamaan hak asasi manusia. Ajaran Islam mula-mula lahir untuk memerangi ketidakadilan dan membela kaum yang lemah. Dalam hal ini termasuk kaum minoritas. Islam juga menghendaki adanya persaudaraan dan kerukunan antar umat. Tidak sedikit ayatayat Al-Quran yang memiliki pesan moral mengenai keadilan, persaudaraan dan kerukunan. Idealnya, dari masa ke masa, Islam bisa menjadi tempat berteduh bagi umat manusia dari ketidakadilan dan kekerasan.

Hal tersebut dapat kita jumpai dalam Al-Quran, diantaranya adalah Q.S. Al-Hujurot ayat 13:

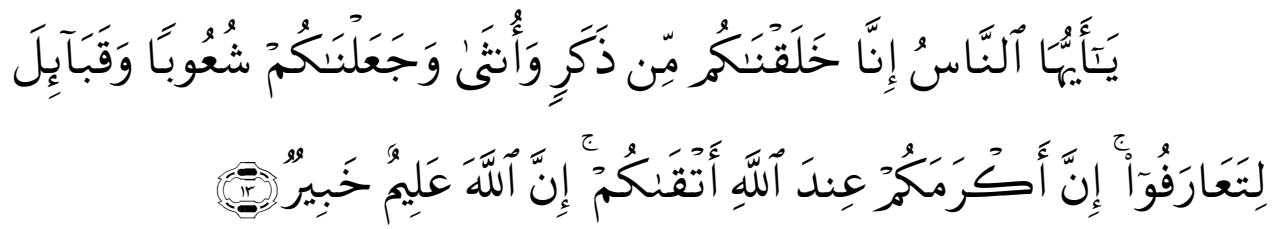

Artinya: Hai manusia, Sesungguhnya Kami menciptakan kamu dari seorang lakilaki dan seorang perempuan dan menjadikan kamu berbangsa - bangsa dan bersuku-suku supaya kamu saling kenal-mengenal. Sesungguhnya orang yang paling mulia diantara kamu disisi Allah ialah orang yang paling taqwa diantara kamu. Sesungguhnya Allah Maha mengetahui lagi Maha Mengenal (Jabal, 2009:517). 
Ayat di atas menunjukkan bahwa, munculnya keragaman dan perbedaan antara yang satu dengan yang lain, mengindikasikan anjuran untuk saling mengenal dan memupuk perdamaian. Manusia yang satu dengan manusia yang lain itu sama dan yang membedakan adalah tingkat ketaqwaan kepada Allah. Secara eksplisit jelas bahwa Islam menghendaki persaudaraan dengan sesama.

Namun dalam perjalanannya, umat muslim tidak selalu merepresentasikan misi awal ajaran Islam. Hal ini bisa dibuktikan dengan adanya banyak kasus kekerasan atas nama agama di negara ini. Indonesia yang kita kenal sebagai negara yang plural dan multikultural dengan mayoritas umatnya yang muslim, ternyata terbukti masih mengidap penyakit eksklusif dan intoleran dalam tubuh agamanya. Kita pasti sudah mengetahui bagaimana kasus Syi'ah yang terjadi di Sampang. Kemudian kasus pembakaran masjid di Tolikara. Selain itu, kasus yang terjadi pada jama'ah Ahmadiyah.

Beberapa kasus di atas hanya sebagian kecil saja. Masih banyak kasus kekerasan atas nama agama di negara ini. Hal yang juga sering terjadi di sekitar kita adalah sikap dan tindakan saling menyesatkan dan menyalahkan kelompok lain yang tidak sejalan. Sebagai contoh, yang masih hangat terjadi adalah penodaan mimbar akademik di dalam institusi pendidikan yang terjadi beberapa waktu lalu di IAIN Tulungagung.

Pada tanggal 29 Maret 2016 lalu, Fakultas Ushuluddin Adab dan Dakwah berencana mengadakan Seminar Internasional and Call for Papers dengan tema The Future of Islamic Civilization between Hopes and Challenges. Acara tersebut mengundang narasumber dari Al-Mustafa International University, Qom Iran, Seyyed Mofid Hoseini Qouhsari. Namun, acara besar tersebut terpaksa dibatalkan karena ada pihak luar yang tidak menyetujui atas nama agama. Lebih parahnya, beberapa dari pihak yang menentang adalah para tokoh agama.

Tidak hanya itu, tanggal 25 Mei mendatang, agenda Institut Transvaluasi yang di usung oleh jurusan Filsafat Agama Fakultas Ushuluddin adab dan Dakwah akan mengadakan diskusi umum mengenai Islam Jawa dengan narasumber Ulil Absor Abdalla. Namun lagi-lagi harus mendapat kecaman pahit dari beberapa masyarakat muslim yang menganggap pemateri tersebut menyesatkan dan harus dijauhkan dari lingkungan kita. Hal ini bisa dilihat dari beberapa akun sosial media yang mengindikasikan keinginan keras membubarkan acara tersebut.

Di bagian atas tadi, penulis menyebut penodaan mimbar akademik karena kelompok yang menentang agenda akademik tersebut membawa namanama akidah dalam ranah keilmuan. Dan hal tersebut adalah tindakan yang merepresi para akademisi, karena tugas akademisi adalah mengkaji dan meneliti. Bayangkan seandainya tradisi berdiskusi harus dibubarkan atas nama agama. Mahasiswa yang bersemangat menambah wawasan keilmuan harus menelan kekecewaan.

Beberapa contoh kecil di atas menunjukkan bahwa, masyarakat muslim kita masih miskin toleransi. Masyarakat muslim kita masih mengidap penyakit egois dalam beragama dan berujung pada sikap menganggap dirinya paling benar dan cenderung menyalahkan yang lain. Islam seakan kehilangan payung pertamanya sebagai solusi atas masalah umat. Islam menjadi gersang dan jauh dari keharmonisan dalam keragaman. Islam seolah menjadi menakutkan bagi beberapa pihak.

513 BRILIANT: Jurnal Riset dan Konseptual Volume 2 Nomor 4, November 2017 
Masduqi (2011:56) menyebutkan bahwa demi tujuan melindungi kesakralan iman dan simbol-simbol agama, kelompok minoritas seakan-akan sah didiskriminasi. Dari sinilah kesakralan dan keimanan seolah-olah sah meminta korban-korban, lalu kekerasan atas nama agama pun sulit dihindarkan. Pernyataan ini benar-benar telah terjadi dalam budaya berIslam masyarakat muslim kita. Nilai humanis dan toleran telah dikotori atas nama agama.

Beberapa catatan diatas mengindikasikan bahwa, ada ketimpangan antara pesan ideal yang diajarkan Islam dengan realita yang terjadi di tengah-tengah kehidupan masyarakat muslim Indonesia. Hal ini senada dengan apa yang disampaikan oleh Maarif (2009:147) Ia mengatakan bahwa sampai abad 21 ini, masih saja ada pihak yang mengharamkan pluralisme, dan karena haram pendukungnya dianggap sesat, bahkan kafir. Hal ini menandakan bahwa, gagasan pluralisme yang berujung pada sikap toleransi masih menjadi momok bagi sebagian orang. Itu artinya, Islam bisa dikatakan telah bergeser dari misi awalnya.

Hal-hal tersebut mendasari penulis untuk melakukan telaah mengenai akar konservatif dan intoleran dalam keberagamaan masyarakat Indonesia, serta mencoba menemukan beberapa solusi atas problem akut tersebut guna menuju kehidupan beragama yang inklusif (Nurjannah, 2013) dan saling memupuk toleransi antar sesama manusia dalam bingkai kebhinekaan Indonesia. Untuk melakukan kajian ini, penulis menggunakan studi kasus dan studi pustaka melalui literatur-literatur yang relevan.

\section{PEMBAHASAN}

\section{Sebab-Sebab sikap eksklusif dan Intoleran dalam beragama}

Banyaknya kekerasan atas nama agama dan sikap saling mengafirkan yang terjadi di masyarakat Indonesia, bukan tidak berdampak pada budaya negara kita yang notabene mengakui adanya pluralisme dan multikulturalisme. Sikap saling menyalahkan dan menyesatkan tersebut akan menjadi kebiasaan dan berdampak buruk bagi kelangsungan kehidupan beragama kita, baik untuk saat ini maupun untuk masa yang akan datang.

Ada banyak faktor yang menyebabkan tumbuh suburnya sikap saling menyalahkan dan kekerasan yang terjadi dalam keberagamaan masyarakat Indonesia. Faktor-faktor tersebut ada kalanya dari masyarakat muslim Indonesia itu sendiri, ada kalanya disebabkan oleh pengaruh dari luar yang masuk ke dalam pemahaman mereka. Berikut beberapa faktor yang menyebabkan munculnya sikap eksklusif dan intoleran dalam beragama.

\section{Perbedaan Aliran dan fanatisme berlebihan}

Dalam banyak literatur, kita tahu bahwa Islam mengalami pasang surut dalam perjalanannya. Pada masa Nabi dan khulafaur rasyidin, Islam cenderung memiliki pemahaman satu arah dan ekspresi keIslaman relatif tunggal. Namun kemudian, pada perkembangan selanjutnya, Islam mengalami pergolakan politik yang cukup menegangkan. Dan hal itu merupakan tonggak awal munculnya perbedaan golongan di antara umat muslim. Sebut saja perang siffin yang melahirkan dua aliran, Khowarij dan Syiah pada masa itu.

Namun jauh sebelum itu, Al-Quran sesungguhnya pernah mengisahkan suatu pertentangan yang pernah terjadi dan akan terus terjadi. Kita pasti pernah mendengan kisah Qabil dan Habil yang dimuat dalam Al-Quran. Eko Supriyadi 
yang melakukan studi atas pemikiran Syari'ati (Supriyadi, 2003:169) bahwa pertarungan antara Qabil dan Habil adalah pertarungan antara dua kubu yang saling berlawanan yang berlangsung sepanjang sejarah, dalam bentk dialektika sejarah. Sejarah, dengan demikian, seperti halnya manusia sendiri, terdiri atas proses dialektis. Kontradiksi yang bermula dari pertarungan Qabil dan Habil.

Sesungguhnya, menurut hemat penulis, perbedaan aliran dan pemahaman itu sah-sah saja. Dan hal tersebut adalah sunatullah yang niscaya. Namun yang menjadi masalah adalah, ketika perbedaan faham dan aliran tersebut mengakibatkan satu pihak merepresi pihak yang lain. Terjadi tindakan menyalahkan dan menyesatkan. Tentu hal itu bertentangan dengan ajaran agama yang memerintahkan umat muslim untuk saling mengenal dan memupuk persaudaraan. Sejauh yang penulis amati dalam berbagai literatur, perbedaan dan pertentangan antar madzhab senantiasa terjadi dalam konteks kesejarahan umat muslim. Bahkan hingga saat ini, sikap saling menentang antar satu aliran ataupun antar organisasi masih saja tumbuh subur di tengah-tengah masyarakat Indonesia.

Tidak hanya itu, pertentangan-pertentangan yang merupakan warisan masa lalu itu tetap diwariskan dari generasi ke generasi selanjutnya hingga saat ini. penulis mengatakan demikian karena memang doktrin anggapan sesat terhadap suatu kelompok terus menerus disuarakan sehingga menjadi warisan yang akan diberikan kepada generasi di bawahnya.Akibatnya, pola doktrinasi yang terus dijalankan tersebut menumbuhkan fanatisme yang berlebihan dan membawa kepada penganut aliran atau paham kepada sikap intoleran, saling menyalahkan dan menyesatkan.

Muslim Indonesia, kaitannya dengan hal itu, adalah salah satu yang menerapkan sikap intoleran tersebut. Bahkan menurut Yenni Wahid yang saat ini menjadi direktur The Wahid Institute pernah menyatakan dalam salah satu stasiun televisi bahwa saat ini tidak sedikit terjadi toleransi terhadap sikap intoleran. Seperti halnya pernyataan Sya'ban yang dikutip oleh Misrawi (2010:160). Kita sesungguhnya tidak mengerti toleransi diantara kita, baik pada level individu maupun kolektif, kelompok, organisasi mapupun politik. Bahkan pada tataran tertentu, kita senantiasa memupuk perseteruan diantara kita, baik dalam satu aliran, satu partai, satu bangsa maupun satu golongan. Kita sudah menyaksikan dengan seksama peperangan, pembantaian dan pembunuhan masal yang disebabkan krisis toleransi. Pemberangusan kebebasan berpendapa dan peminggiran kelompok lain.

Pernyataan di atas tidak mengherankan karena hampir tidak ditemukan suatu daerah, negara ataupun organisasi yang tidak terjadi kasus intoleran. Kekerasan seolah bukan hal yang mengagetkan lagi di telinga kita. Beberapa pernyataan di atas juga memunculkan hal yang patut digarisbawahi bahwa penyebab utama munculnya kasus intoleran adalah perbedaan aliran, madzhab, ideologi maupun faham yang berujung pada fanatisme yang berlebihan.

\section{Kungkungan otoritas masa lalu}

Masa lalu yang terjadi dalam dimensi ruang dan waktu yang sama sekali berbeda dengan zaman kita, hingga saat ini masih dibaca dan dipelajari. Hal tersebut tidak masalah karena sebagai bentuk apresiasi atas karya masa lalu dan sebagai pelajaran berharga untuk masa kini. Namun, akan menjadi masalah serius 
jika otoritas sejarah di masa lalu masih tetap dipraktikan, bahkan terjadi pemaksaan pengamalan ajaran.

Hal di atas tentunya menimbulkan beberapa ketidakcocokan dengan kondisi dan situasi masa kini. Akibatnya, ajaran Islam seolah merepresi umat agar mengikuti ajaran yang tidak relevan tersebut. Konsekuensinya, Islam dipandang sebagai agama yang kaku dan konservatif. Al-Jabiri (2014:71) menyebutkan sesungguhnya, sejarah kultural Arab yang dominan sekarang adalah sekedar daur ulang, pengulangan, serta reproduksi dalam bentuk yang buruk, terhadap sejarah yang ditulis nenek moyang kita dibawah tekanan pertentangan yang terjadi saat itu. Oleh karena itu, kita terpenjara dalam pandangan, konsep, dan metode klasik yang mengarahkan mereka dimana hal ini secara tanpa disadari memaksa kita terlibat dalam pertarungan masa lalu dan problematikanya, menjadikan masa kini kita disibukkan oleh berbagai problematika masa lalu dan pertentangannya.

Pernyataan Al-Jabiri di atas menunjukkan bahwa salah satu penyebab terjadinya intoleran dan kekerasan atas nama agama adalah terkungkungnya masyarakat oleh otoritas masa lalu yang memiliki sejarah pertentangan. Penulis menyebutnya warisan kelam sejarah karena otoritas masa lalu yang terus ditulis dan diceritakan dari masa ke masa, akan menyebabkan seseorang menanam kebencian dalam diri tanpa evaluasi terlebih dahulu.

Jika kita lihat, pertentangan dalam konteks Islam memang tertulis dalam sejarah. Tidak hanya itu, pertentangan dan perpecahan tersebut juga tertulis dalam ilmu yang berwujud karya para ulama', sehingga secara tidak langsung generasi Islam diajari untuk saling membenci.

Tulisan sejarah otoritas masa lalu, bukan tidak berdampak pada masa kini. Justru sangat berdampak hebat karena efeknya masih saja dirasakan hingga saat ini. Bahkan kekerasan yang awalnya hanya dalam hati dan ucapan, berujung pada kekerasan fisik hingga kematian. Hal ini jelas sangat melangar hak asasi manusia.

Masduqi (2011:64) menyebutkan dalam bukunya Berislam secara Toleran bahwa meskipun toleransi dapat ditemukan akar-akarnya dalam tradisi filsafat dan teologi, tidak bisa dipungkiri bahwa pada periode tertentu spirit toleransi ini tergilas oleh kecenderungan mayoritas ulama' yang terkungkung oleh dogmatisme, intoleransi, dan fanatisme.

Pernyataan diatas menunjukkan bahwa sebagian orang terdepan Islam yang biasa kita sebut dengan ulama' merupakan aktor yang terjebak dalam kungkungan otoritas tradisi. Dan hal tersebut terjadi dari masa ke masa hingga saat ini. akibatnya, Islam menjadi kaku dan bersikap intoleran. Bahkan, secara lebih dalam, Irwan Masduqi menyatakan bahwa eksklusifisme dan fanatisme merupakan penyakit kekauan mental yang disebabkan oleh doktrin dogmatis.

\section{Anggapan bahwa Arab sebagai prototype Islam ideal}

Islam yang lahir di Arab, merupakan potret Islam ideal pada masa itu. Dan itu konsekuensi logis dari suatu agama yang hadir dalam rangka menjadi penyempurna ajaran agama terdahulu. Harus diakui bahwa hadirnya Nabi Muhammad sebagai pembawa ajaran adalah utusan sempurna yang sepatutnya kita teladani ajarannya.

Namun, fakta sejarah berbicara bahwa Islam dari masa ke masa sejak lahirnya, telah mengalami perluasan yang menuntut perbedaan situasi, kondisi 
hingga perbedaan ruang dan waktu. Masyarakat muslim Arab, tidak sama dengan masyarakat muslim Indonesia. Kondisi geografis dan budaya Arab sama sekali berbeda dengan kondisi geografis dan budaya Indonesia. Konsekuensinya, wajah Islam di Arab akan berbeda dengan wajah Islam di Indonesia karena pengaruh budaya yang ada.

Oleh karena itu, memaksakan ke-idealan Islam di Arab pada masa turunnya wahyu ke dalam konteks keindonesiaan akan menjadikan wajah Islam Indonesia terasa gersang dan menakutkan. Bahkan, saat ini pun masih banyak pendapat yang merekomendasikan Indonesia menganut sistem khilafah yang notabene ideal bagi masanya. Namun, menjadi tidak relevan untuk dipakai dalam negara yang plural dan multicultural ini.

Lebih lanjut lagi, membawa paham Arab sebagai wajah Islam yang ideal dalam konteks Indonesia, akan memunculkan sikap menentang atas hal baru yang hadir dan menjadikan Islam sebagai agama tertutup. Ini artinya, secara perlahan akan menanamkan sikap eksklusif dan intoleran dalam tubuh Islam itu sendiri. Sehingga, sah-sah saja bila tiba-tiba ada pihak yang mengklaim bahwa Islam menjadi sumber pertentangan dan permusuhan.

\section{Pemahaman keagamaan yang parsial}

Ada ungkapan bahwa, tidak akan ada satu orang pun yang bisa sampai pada kehendak Allah. Tidak ada satu orang pun yang mampu menafsirkan AlQuran sesuai dengan apa yang di maksud Penuturnya. Manusia hanya memahami pesan Islam sesuai dengan kemampuan yang dimiliki. Namun bukan berarti bisa menafsirkan pesan Islam sesuai dengan kehendak hatinya karena Islam memiliki kata kunci tertentu yang bisa dipakai oleh setiap zaman dan tempat.

Berbicara tentang pemahaman agama, pemahaman yang parsial (Mustaqim, 2014:109) ternyata memiliki pengaruh tersendiri bagi keberlangsungan umat beragama. Pemahaman yang parsial menyebabkan seseorang hanya mengakui kebenaran tunggal, monolitik. Sehingga tidak ada tempat bagi kultur toleransi karena paham di luar dirinya adalah salah dan menyesatkan.

Jika kita menoleh pada sejarah, karya-karya Islam yang muncul pada periode klasik dan pertengahan, kita akan menjumpai metode tafsir yang menggunakan metode tahlili (Khaeruman, 2014:9). Kelemahan dari metode tahlili adalah model penafsiran yang sifatnya terpotong-potong antara ayat yang satu dengan ayat lain yang memiliki tema yang sama. Sehingga, konsekuensi logis dari model karya tafsir seperti itu adalah pemahaman ajaran Islam yang parsial. Sehingga hasilnya pun tidak kompehensif.

Sebagai contoh, misalnya pemahaman mengenai ayat perang. Jika hanya melihat pada ajaran tentang perang, maka yang dipahami oleh umat muslim adalah perintah untuk perang yang berarti jihad dan mendapat pahala. Namun di ayat yang lain, ada perintah yang menganjurkan umat muslim untuk memupuk keadilan dan kedamaian. Hal ini jelas bahwa, pemahaman yang sepotong-potong terhadap ajaran Islam, akan rentan terhadap datangnya sikap intoleran dalam beragama. 


\section{Ajaran Islam sebagai Solusi atas Problem Umat}

Setelah menyebutkan beberapa faktor yang menyebabkan munculnya sikap konservatif dan intoleran. Maka, kali ini penulis akan mencoba memaparkan sebuah pasan universal bahwa Islam merupakan agama yang hadir dengan misi menawarkan solusi atas problem yang terjadi di tengah masyarakat. Hal ini terbukti dengan adanya konsep asbab an-nuzul (Badruzzaman, 2016: 34-35) dalam kajian ilmu Al-Quran.

Tidak sedikit riwayat yang menyebutkan bahwa suatu ayat diturunkan atas dasar problem yang terjadi. Selain itu, ada juga ayat yang turun dilatarbelakangi oleh pertanyaan-pertanyaan sahabat. Hal ini tampak jelas bahwa Islam pada masa turunnya Al-Quran merupakan sumber yang menyelesaikan permasalahan, bukan sumber masalah itu sendiri. Namun, dalam perkembangannya, Ajaran Islam kerap kali dianggap sebagai sumber pertentangan dan permusuhan.

Disamping sebagai solusi atas problem, Islam juga mengajarkan untuk melawan ketidakadilan dan ketertindasan. Hal ini senada dengan apa yang diungkapkan Badruzzaman (2007:41) bahwa katika Al-Quran mengisahkan perjuangan para Nabi menegakkan kebenaran, sesungguhnya, ia juga mengisahkan perjuangan mereka melawan penindasan dan perjuangan mereka membela orang-orang tertindas.

Dari uraian di atas, dapat diambil pemahaman bahwa Islam tidak menyukai kedhaliman. Islam tidak menyukai diskriminasi atas kaum minoritas. Islam adalah payung yang bisa dijadikan tempat berteduh oleh orang-orang yang lemah. Islam mengajarkan kedamaian dan keharmonisan dalam kehidupan bermasyarakat.

Disamping hal di ats, Islam juga tidak menyukai pemaksaan agama kepada pihak lain, hal ini tertulis dalam Al-Quran surah Al-Baqoroh ayat 256:

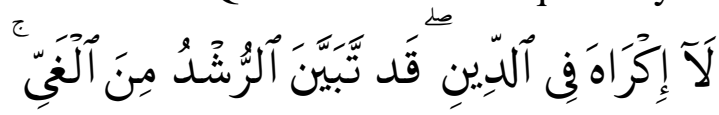

Tidak ada paksaan untuk (memasuki) agama (Islam); Sesungguhnya telah jelas jalan yang benar daripada jalan yang sesat.

Ayat di atas dengan gamblang menerangkan tentang konsep kebebasan beragama dalam ajaran islam. Agama Islam tidak dipaksakan keada siapapun karena memang tidak bisa dan tidak boleh. Tidaklah benar tindakan memaksa seseorang memeluk suatu agama, dan tidak praktis pula Islam membenarkan cara itu, bahkan mengutuknya (Rachman, 2011:91).

Jika kita kembali kepada fenomena yang penulis sampaikan di awal, kita akan mengetahui bahwa Islam yang secara ideal berperan sebagai penengah atas problem umat, telah mengalami pergeseran dalam realitasnya. sebagian umat muslim telah merepresentasikan Islam secara linier dan hanya mengakui satu kebenaran, yaitu sebatas Islam dalam pemahamannya. Sehingga, lambat laun, keyakinan pada kebenaran tunggal yang tidak diimbangi dengan sikap saling menghargai akan memunculkan sikap menyalahkan golongan lain.

Abdalla (2007:15) menyatakan bahwa Islam menghormati penuh hak-hak semua orang untuk berpendapat. Selama orang itu menyatakan pendapatnya dengan cara yang damai, beradab, sopan dan tidak memaksakan, maka umat Islam wajib menghormatinya. 
Pernyataan Ulil Absor Abdalla di atas sesuai dengan tujuan ajaran Islam, yaitu sebagai agama yang saling menghargai dan menghormati kebebasan berpendapat selama dalam koridor yang tidak melanggar hak asasi manusia. Islam bukanlah agama yang menjadi sumber masalah bagi kehidupan bermasyarakat, melainkan solusi untuk melawan ketidakadilan dan kedhaliman.

\section{Sikap Toleran sebagai Pilar Keberagamaan yang Humanis}

Menanggapi berbagai problem intoleran dan kekerasan atas nama agama, sesungguhnya hal penting yang tidak bisa diabaikan adalah rekontruksi budaya inklusif dan toleran (Miswari, 2010:61) di tengah keberagaman budaya dan agama di Indonesia. Budaya inklusif dan toleran tersebut diharapkan akan menjadikan keberagamaan yang humanis.

Spirit pluralitas dan toleransi sesungguhnya sudah muncul sejak zaman Nabi Muhammad. Sebagai contohnya adalah pengukuhan Piagam Madinah yang bertujuan membangun masyarakat yang plural dimana antara kaum Ansar, Muhajirin dan umat Yahudi disatukan dalam satu komunitas (Masduqi, 2011:74).

Toleransi menjadi pilar penting bagi keberlangsungan agama di Indonesia karena Islam sendiri telah menetapkan tidak ada paksaan dalam agama. hal tersebut mengindikasikan larangan memaksa orang lain untuk mengikuti suatu agama, termasuk faham kegamaan. Pernyataan tersebut bisa dimaknai bahwa Islam sesungguhnya menghendaki sikap saling toleransi antar umat dan golongan. Ahmad Syafii Maarif menyatakan bahwa jalan yang terbaik dan sah bagi seorang muslim dalam kehidupan bermasyarakat adalah mengembangkan kultur toleransi (Maarif, 2009:188).

Lebih lanjut lagi, toleransi menjadi sesuatu yang tidak bisa ditolak sebagai solusi kekerasan atas nama agama karena Al-Quran secara eksplisit menguatkan adanya eksistensi keragaman suku, bangsa, agama, dan bahasa. Semua keragaman tersebut akan menjadi harmonis, aman dan damai jika mereka memiliki tingkat toleransi yang tinggi.

Misrawi menyatakan bahwa secara sosiologis, membangun masyarakat yang toleran memang tidak mudah, karena sebagian sejarah manusia pada hakikatnya adalah sejarah intoleransi. Realita sosial masyarakat selalu disuguhi dengan peristiwa yang mengisahkan peristiwa intoleran. Pada akhirnya, menurutnya hal itu mempengaruhi sejarah perjalanan agama dalam suatu sejarah karena sejarah agama bisa menjadi sejarah intoleransi (Miswari, 2010:159).

Kemudian selanjutnya, Miswari (2010:157) juga mengutip hadis nabi yang artinya Agama yang paling dicintai Allah adalah ajaran yang lurus dan toleran (H.R. Abu Syaibah dan Bukhori). Hadis ini jelas menyatakan pentingnya toleransi dalam kehidupan. Oleh karena itu, upaya upaya membangun budaya toleransi harus diprioritaskan, terutama dalam konteks Indonesia yang plural dan multicultural ini.

Toleransi sebagai pilar utama untuk menuju keberagamaan yang inklusif karena toleransi adalah jembatan dan gerbang awal yang mesti digalakkan untuk mencapai kehidupan yang harmonis. Dengan terwujudnya toleransi di antara sesama, maka secara otomatis akan mewujud pula sikap saling menerima, menghargai dan menghormati yang lain.

Pemaparan di atas menunjukkan bahwa, kehidupan berbangsa dan beragama akan mencapai tingkat humanis dan harmonis apabila tertanam budaya

519 BRILIANT: Jurnal Riset dan Konseptual

Volume 2 Nomor 4, November 2017 
toleransi. Sehingga, masyarakat kita, terutama generasi muda semestinya sudah mulai ditanamkan sikap toleransi terhadap sesama dalam dirinya. Bukan mengajarkan fanatisme berlebihan yang berujung pada kekerasan dengan memakai payung agama.

\section{KESIMPULAN}

Kekerasan atas nama agama dan tradisi menyesatkan antar golongan yang terjadi di Indonesia, disebabkan oleh beberapa faktor, pertama, perbedaan aliran dan fanatisme yang berlebihan. Kedua, kungkungan otoritas masa lalu yang terus didengungkan dan dilestarikan hingga saat ini. ketiga, adanya anggapan bahwa Arab merupakan prototype Islam ideal. Keempat, pemahaman umat muslim terhadap ajaran Islam yang parsial. Dilihat dari misi awalnya, ajaran Islam merupakan solusi atas problematika masyarakat. Sehingga jika terjadi kekerasan atas nama agama dan tradisi saling menyesatkan, itu sama sekali bukan ajaran Islam karena bertentangan dengan misi kedatangan Islam sebagai pembela kaum yang lemah dan melindungi kaum minoritas.

\section{SARAN}

Untuk menyelesaikan problem kekerasan atas nama agama dan tradisi saling menyesatkan, merekontruksi budaya toleransi di tengah-tengah kehidupan masyarakat Indonesia adalah salah satu solusi. Toleransi dapat meminimalisir terjadinya pertentangan dan kebencian yang berujung pada kekerasan antar golongan. Sehingga, kehidupan beragama dan berbangsa yang humanis dapat diwujudkan di tengah-tengah bangsa yang plural dan multikultural ini.

\section{DAFTAR RUJUKAN}

Abdalla, Ulil Absor. 2007. Menyegarkan Kembali Pemikiran Islam Bunga Rampai Surat-Surat Tersiar. Jakarta: Nalar.

Al-Jabiri, Muhammad Abid. 2014. Formasi Nalar Arab (Takwin Al-'Aql AlArabi), terj. Imam Khoiri. Yogyakarta: IRCiSoD.

Jabal. 2009. Al-Quran dan Terjemahnya. Bandung: Jabal.

Badruzzaman, Abad. 2007. Teologi Kaum Tertindas. Yogyakarta: Pustaka pelajar. Badruzzaman, Abad. 2016. Cerdas Membaca Zaman Berbekal Ulumul Quran, Jakarta: Saadah Pustaka Mandiri.

Khaeruman, Badri. 2004. Sejarah Perkembangan Tafsir Al-Quran, Bandung: Pustaka Setia.

Maarif, Ahmad Syafii. 2009. Islam dalam Bingkai Keindonesiaan dan Kemanusiaan, Bandung: Mizan Pustaka.

Masduqi, Irwan. 2011. Berislam secara Toleran. Bandung: Mizan Media Utama.

Misrawi, Zuhairi. 2010. Al-Quran Kiab Toleransi, Tafsir Tematik Islam Rahmatan lil 'Alamin. Jakarta: Pustaka Oasis.

Mustaqim, Abdul. 2014. Dinamika Sejarah Tafsir Al-Quran, Yogyakarta: Adab Press.

Nurjannah, Nisa. 2013. Pemikiran Islam Inklusif dalam Kehidupan Sosial Beragama dan Relevansinya dalam Pendidikan Islam. Yogyakarta.

Rachman, Budhy Munawar. 2011. Islam dan Liberalisme. Jakarta: Friedrich Naumann Stiftung. 
Supriyadi, Eko. 2003. Sosialisme Islam Pemikiran Ali Syari'ati, Yogyakarta: Pustaka pelajar. 